|Araştırma Makalesi / Research Article |

\title{
Cumhuriyet Dönemi Türkçe Dersi Öğretim Programlarında (1924-2018) Dil Becerilerinin Öğretiminde Kullanılan Tekniklerin İncelenmesi
}

\section{Exploring Techniques Used for Teaching Language Skills in the Republican Era Turkish Curricula (1924-2018)}

\section{Ümit Yıldız ${ }^{1}$, Burak Asma²}

Anahtar Kelimeler
Türkçe dersi öğretim
programı
dil becerileri
öğretim teknikleri
tarihsel inceleme
içerik analizi
Keywords
Turkish curriculum
language skills
teaching techniques
historical review
content analysis

Başvuru Tarihi/Received 08.03.2019

Kabul Tarihi /Accepted 17.10.2019

\section{Öz}

Bu çalışma, Cumhuriyet Dönemi Türkçe Dersi Öğretim Programlarında temel dil becerilerinin öğretiminde kullanılan teknikleri belirlemeyi amaçlamaktadır. Bu amaçla, 1924-2018 yılları arasında yayınlanan ilk ve orta öğretim Türkçe dersi programları çalışmanın veri kaynağı olarak belirlenmiştir. Nitel araştırma yöntemlerinden doküman incelemesi tekniğinin araştırmanın merkezinde kullanıldığı bu çalışmada, ilgili programlarda temel dil becerilerinin öğretiminde kullanılan teknikler iki alan uzmanı tarafından içerik analizi yapılarak incelenmiştir. Elde edilen bulgular betimsel istatistiki veriler aracılığıyla tablolaştırılmış, bulgulara ilişkin ifadeler ortaya konmuştur. Çalışma sonucunda, programlarda temel dil becerileri arasından en çok okuma becerisine ilişkin öğretim tekniklerine yer verildiği, bu beceriyi sırasıyla yazma, konuşma ve dinleme becerisinin takip ettiği görülmüştür. Programlarda başvurulan tekniklere ilişkin bulgulara bakıldığında, okuma becerisinin öğretiminde öne çıkan tekniklerin edebi metin okuma ve sesli okuma; yazma becerisinde serbest yazma; dinleme becerisinde katılımsız dinleme ve konuşma becerisinde ise serbest konuşma tekniğinin kullanıldığı ortaya çıkmışır. Çalışmadan elde edilen bulgular, ilgili literatür ile desteklenerek tartışılmıştır.

\section{Abstract}

This study aims to reveal the techniques used for teaching language skills in the Republican Era Turkish Curriculum. To attain this goal, the primary and secondary Turkish curriculum published between the years 1924-2018 were determined as the data source of the study. The study adopted the document analysis technique of qualitative research methods in the centre of the study and techniques used for teaching basic language skills were analysed by two field experts through the content analysis technique. The findings were illustrated by using descriptive statistics in tables, the related statements were added. The results showed that among the basic language skills, the curriculum gave wide coverage to the techniques used in teaching reading comprehension skills, followed by writing, speaking and listening skills respectively. Considering the findings of the techniques used in the curriculum, the prominent techniques were literary text reading, reading aloud in reading comprehension skills; free writing in writing skills; free listening in listening skills; and free speaking in speaking skills. The research findings were discussed with the relevant literature.

${ }^{1}$ Akdeniz Üniversitesi, Eğitim Fakültesi, Türkçe Eğitimi Anabilim Dalı, Antalya, TÜRKiYE; https://orcid.org/0000-0003-0415-8051

${ }^{2}$ Akdeniz Üniversitesi, Eğitim Fakültesi, Türkçe Eğitimi Anabilim Dalı, Antalya, TÜRKiYE; https://orcid.org/0000-0002-3602-3867 
Extended Abstract

\section{Introduction}

In today's world, a nation needs a well-established education system to sustain its development in different fields. The education system, which is the most crucial resource that maintains the qualified manpower of countries, appears as an indispensable factor between political and social plans in terms of shaping the current situation and the future of the countries and determining its place in the international platform. In recent years, developments in technology have changed the role of the education system and brought countries closer together. With this change and development, communication across countries has gained importance and that paved the way for intercultural exchange. In addition to the development of the common language of communication, the countries have also attached importance to their language developments so that they will not remain under the influence of other languages. Turkey was one of the countries which carried out various changes and innovations in its curriculum. From the early stages, mother-tongue teaching activities were carried out systematically so that students can effectively communicate in four basic language skills (reading, writing, listening and speaking). Besides, the grammar was taught with other language skills in an integrative way, so the students developed the theoretical background of the rules, practices and concepts of their language. Despite investments and regulations in the field of education in recent years, our country ranking in international researches shows that we could not reach the desired level. In particular, when we look at the research results of research results such as International Student Assessment Program (PISA) in which many countries participated, it is observed that our country falls behind other countries in terms of its ability to understand its own language. This situation requires examining the current Turkish course curriculum and determining the deficiencies and overcoming them in the new program.

\section{Method}

This is a document analysis study which aims to determine techniques used for teaching language skills in the Republican Era Turkish Curricula (1924-2018) and present the findings holistically. This method, which is defined as combining and analysing written and/or visual data sources which contain fact/facts about the research subject, can be used in both quantitative and qualitative types of research. While it can be used as a supplementary research technique in many fields, especially in educational and social sciences, it can also be conducted as a sole method in scientific research. This method was found appropriate to the objectives and scope of the research because the present study aims to determine techniques used for teaching basic language skills in the curriculum. Since it was based on document review, any further data collection techniques were not used in this study. The research data consisted of 19 Turkish Curricula published in the Republican Era. The data proceeded in the study were gathered by scanning the current curriculum and electronic archives of the Ministry of Education. The collected data were compiled comparatively and systematically and any interpretation was not added to the analysis process. The data were analysed through content analysis technique. The findings were grouped under the predetermined categories which consisted of techniques used for teaching basic language skills (reading, writing, listening and speaking). The obtained findings were presented in tables by supporting relevant excerpts.

\section{Result and Discussion}

The research results were presented under the sub-research questions. When the findings were examined, it was found that literary text reading and reading aloud (89.42 \%) were the most commonly used techniques used for teaching reading skill. They were followed by silent reading with the ratio of ( $84.16 \%)$. Even though other teaching techniques were not commonly used as much as those techniques in the curriculum, their ratios were as follows: summarising (73.64 \%); informational text reading and memorising (63.12\%); intensive reading (57.89\%); reading theatre(42.08\%); argumentative reading (31.56\%); reading by taking notes and critical reading (26.03\%); reading by questioning (21.04\%); reading in groups and scanning (15.78\%); selective reading $(10,52 \%)$ and reading by associating with texts(5.26\%).

Besides, the findings related to writing skill revealed that the technique "free writing" ranked number one out of other teaching techniques used in this skill. 14 curriculum out of 19 used this technique for teaching writing skill. According to the results, other techniques' ratios were summarising (52.6\%); writing a new text from the previous one and critical writing (31.6\%); text completion and writing in groups (26.3\%); note-taking, filling the banks, writing by selecting words or concepts, controlled writing, guided writing, creative writing, guessing, rewriting and writing through emotions (15.78\%).

According to the research results, it was also found out that the curriculum examined in the study mainly used free listening technique (31.56 \%) to teach and practice the listening skill. This technique was followed by listening by taking notes and critical listening (21.04\%); participatory listening, listening by putting himself in the speaker's place, creative listening and selective listening (15.78\%) and listening in groups.

Lastly, the research results indicated that free speaking (63.12\%) was the most commonly used technique among others. Compared to this technique, critical speaking, participatory speaking, discussion, speaking by putting himself in someone else's place and creative speaking had a ratio of $31.56 \%$. While persuasive speaking had the ratio of $21.04 \%$, guided speaking and speaking by selecting words or concepts the ratio of $15.78 \%$. 
GiRiş

Ülkelerin nitelikli insan gücünü besleyen en önemli kaynak olan eğitim sistemi, ülkelerin gerek mevcut durumunu gerekse geleceğini şekillendirmesi ve uluslararası alandaki konumunu belirleyici özelliğe sahip olması bakımından politik ve sosyal planlamalar arasında vazgeçilemez bir unsur olarak karşımıza çıkmaktadır (Korkmaz, 2005). Son yıllarda, teknoloji alanında gerçekleşen gelişmeler eğitim sisteminin önemini arttırmış, ülkeleri birbirine yaklaştırmıştır. Bu değişim ve gelişim ile birlikte ülkelerarası iletişim önem kazanmış, kültürlerarası alışverişin yolu açılmıştır (Temel Eğinli, 2011). Ortak iletişim dilinin gelişmesinin yanı sıra ülkeler diğer dillerin etkisi altında kalmaması için kendi dillerinin gelişimine de önem vermiştir. Ülkemizde özellikle yapılandırmacı yaklaşım temelinde hazırlanan Türkçe dersi öğretim programıyla birlikte öğrencilerin dilsel, zihinsel, kişisel ve sosyokültürel becerilerinin geliştirilmesi amaçlanmış, öğrencilerin anlama ve anlatma becerilerini yetkin bir şekilde kullanan bireyler olarak yetiştirilmesi için düzenlemeler yapılmıştır (Göçer, 2015). Bu yaklaşımın temel alınarak oluşturulan Türkçe Öğretim Programlarında çoklu zekâ, öğrenci merkezli öğrenme, beyin temelli öğrenme, bireysel farklılıklara duyarlılık, sarmal ve tematik yaklaşım, beceri yaklaşımı, yapılandırıcı okuma, anlama ve yazma öğretimi modelleri gibi çeşitli yaklaşım ve modellerden yararlanılmıştır (Güneş, 2014). Türkçe öğretimi yalnızca anlama ve anlatma becerilerinin öğretimiyle sınırlı kalmamış, aynı zamanda yaratıcı düşünme, organize etme, analiz-sentez yapma, sıralama ve değerlendirme gibi bilişsel becerilerinin de gelişimine önem verilmiştir. İlköğretim kademesinden itibaren sistematik bir şekilde anadil öğretim faaliyetleri gerçekleştirilerek öğrencilerin dört temel dil becerisinde (okuma, yazma, dinleme, konuşma) etkili iletişim kurabilmeleri sağlanmaya çalışılmıştır. Bunun yanı sıra, dil bilgisi alanı diğer dil becerileriyle bütünleşik olarak öğretilerek öğrencilerin kendi dillerine ait kural, uygulama ve kavramlara ilişkin teorik altyapıları geliştirilmiştir (Güneş, 2013). Yapılandırmacı yaklaşım temelinde hazırlanan Türkçe Öğretim Programı öğretmenlerin de rolünü değiştirmiş, onları otoriter konumdan uzaklaştırarak eğitim öğretim sürecinde yönlendirici rol üstlenmelerini sağlamıştır. Bu sayede öğrencilerin öğretim programındaki hedeflere kendi çabalarıyla, yaparak ve yaşayarak ulaşabilmelerine ön ayak olunmuştur.

Öğretim programındaki değişikliklere rağmen öğretim sürecinde geleneksel öğretim anlayışını benimseyen öğreticilerin bu anlayışı devam ettirmesi programda tayin edilen hedeflere ulaşılmasını geciktirmiş, eğitim öğretim sürecinin arzu edildiği gibi ilerlemesine engel olmuştur (Akpınar ve Gezer, 2010). Özellikle ilk ve ortaöğretim kademelerinde karşılaşılan bu tür uygulamalar öğrencilerin eğitim öğretim hayatının geri kalanında kalıcı izler bırakmıştır. Kişisel tecrübeler temel alınarak yürütülen süreç, farklı ürünlerin ortaya çıkmasına, öğrenciler arasında öğretim süreci kaynaklı seviye farklılıklarının meydana gelmesine sebep olmuştur. Ancak, mevcut Türkçe dersi öğretim programında olduğu gibi diğer programlarda da eğitim öğretim faaliyetleri gerçekleştirilirken kullanılması gereken yöntem ve tekniklere ilişkin yönergeler yer almaktadır. Fen ve matematik gibi sayısal becerileri değil de öğrencilerin sözel becerilerinin geliştirilmesini amaçlayan dil öğretiminde bu konuya ayrı bir yer ayrılması gereklidir. Öğrencilerin bireysel farklılıkları, farklı öğrenme türlerine sahip olması, farklı hazırbulunuşluk düzeylerinde yer alması gibi etkenler eğitim öğretim sürecinde genel geçer bir öğretim tekniğinin kullanılmasını zorlaştırmaktadır. Bu nedenle, öğretmenlerin farklı öğretim tekniklerini uygulayarak daha geniş kitlelere etkili bir şekilde ulaşabilmesi amaçlanmaktadır. Alan yazında dil öğretim sürecinde anlama ve anlatma becerileri bakımından çeşitli öğretim teknikleri ele alınmaktadır. Okuma becerisine ilişkin 17 (tam okuma, seçmeli okuma, öğretici metin okuma, edebi metin okuma, sesli okuma, sessiz okuma, göz atarak okuma, özetleyerek okuma, not alarak okuma, grup olarak okuma, soru sorarak okuma, okuma tiyatrosu, ezberleme, metinlerle ilişkilendirme, tartışma, hızlı okuma, eleştirel okuma); yazma becerisine ilişkin 15 (not alma, özet çıkarma, boşluk doldurma, kelime ve kavram havuzundan seçme, serbest yazma, kontrollü yazma, güdümlü yazma, yaratıcı yazma, metin tamamlama, tahminde bulunma, bir metni kelimeleriyle tekrar oluşturma, bir metinden yeni bir metin oluşturma, duyulardan hareketle yazma, grup olarak yazma, eleştirel yazma); dinleme becerisine ilişkin 8 (katımlı dinleme, katılımsız dinleme, not alarak dinleme, empati kurarak, grup halinde dinleme, yaratıcı dinleme, seçici dinleme, eleştirel dinleme) ve konuşma becerisine ilişkin 9 (serbest konuşma, yaratıcı konuşma, ikna etme, eleştirel konuşma, katılımlı konuşma, tartışma, empati kurarak konuşma, güdümlü konuşma, kelime ve kavram havuzundan seçerek konuşma) farklı teknik öne çıkmaktadır. Bu teknikler aracılığıyla dil öğretim sürecinin kapsayıcı ve etkili olması hedeflenmektedir. Bu nedenle, anadilimizin öğretiminin çerçevesini belirleyen Türkçe dersi öğretim programının da bu teknikleri içermesi elzemdir.

Ülkemizde, son yıllarda eğitim alanında yapılan yatırımlara ve düzenlemelere rağmen uluslararası araştırmalardaki ülke sıralamamız arzu edilen düzeye ulaşılamadığını ortaya koymaktadır. Özellikle, Uluslararası Öğrenci Değerlendirme Programı (PISA) gibi birçok ülkenin katıldığı araştırma sonuçlarına baktığımızda ülkemizin kendi dilini anlama becerisi bakımından diğer ülkelerin gerisinde kaldığı görülmektedir (Anıl, Özer Özkan ve Demir, 2015). Bu durum, mevcut Türkçe dersi öğretim programın incelenmesini ve eksikliklerinin tespit edilerek yeni programda bunların giderilmesini gerektirmektedir.

Bu çalışma, Türkçe öğretiminde kullanılan öğretim tekniklerinin tarihsel haritasını çizerek Cumhuriyet Dönemi Türkçe Dersi Öğretim Programlarında dil becerilerinin öğretiminde kullanılan teknikleri tespit etmeyi amaçlamaktadır. Bu kapsamda, programlarda anlama ve anlatma becerilerinin öğretiminde başvurulan teknikler tespit edilerek anadil öğretim sürecindeki yönelimlerimiz ortaya konulacaktır.

Alanyazında Türkçe dersi öğretim programıyla ilgili çalışmalara baktığımızda programın farklı yönlerden incelendiği görülmektedir.

Aslan (2011) “1924 ilk Mektepler Müfredat Programını” incelemiş çalışma sonucunda programda Tevhid-i Tedrisat Kanunu'na uyumlu hale getirmek amacıyla yapılan düzenlemeleri ortaya koymuştur. Ayrıca, programda "Yaşam için gerçek yaşam içinde eğitim" felsefesinin benimsendiğini; programın teoriye dayalı öğretimin aksine deneye, gözleme ve uygulamaya dayalı öğretim

| Kastamonu Eğitim Dergisi, 2020, Vol. 28, No. 3| 
modelinin yürütüldüğünü ifade etmiştir. Programın hazırlanış sürecinde farklı kesimlerden kişilerin yer alması sayesinde Türkiye Cumhuriyeti'nin tarihsel açıdan ilk programı olmasına rağmen sistematik özellikler taşıdığını ileri sürmüştür.

Temizkan ve Atasoy (2014) Cumhuriyet Dönemi programlarında yazma becerisine odaklanmıştır. 1924-2005 yılları arasındaki 5 Türkçe dersi öğretim programıyla sınırlandırdıkları çalışmalarında yazma becerisini amaçlar, açıklamalar, yöntem, davranışkazanım ve düzeltme-değerlendirme başlıkları altında incelemiş, ele aldıkları programların arasından bu başlıkları içerenleri belirleyerek yazma becerisine ait aktiviteleri belirtmişlerdir. Benzer bağlamda, Girgin (2011) Cumhuriyet Dönemi ortaokul Türkçe dersi öğretimi programlarını çeşitli açılardan ele almış; programların içeriğini, genel ve özel amaçlarıyla karşılaştırmalı gelişim düzeyini ortaya koymaya çalışmıştır. Programlar arasında bazı farklılıklar olduğu belirtilse de ele alınan programların (1929-1930, 1949, 1981) içerdiği eğitim-öğretim etkinlikleri ve amaçları bakımından çağdaş program geliştirme anlayışından uzak bir bakış açısıyla hazırlandığını öne sürmüştür. Ayrıca, bu programların öğrencilerin o dönemki yaşantısıyla uyuşmadığını ve bu yüzden teoriuygulama konusunda kopukluklara neden olduğunu ifade etmiştir.

Balcı, Coşkun ve Tamer (2012) Cumhuriyet Dönemi Türkçe Dersi Öğretim Programlarının genel amaç içerip içermeme durumlarını incelemişlerdir. Verilerin betimsel tablolar aracılığıyla 7 farklı kategoride (okuma becerisi, yazma becerisi, konuşma becerisi, dinleme becerisi, görsel okuma ve sunu becerisi, ulusal değerler ve zihinsel beceriler) sunulduğu bu araştırmada bulgular frekans değerleri dikkate alınarak yorumlanmıştır. Genel amaç içerme durumu bakımından yazma becerisi ( $f=61)$ ilk sırada yer alırken, bu beceriyi sırasıyla okuma $(f=48)$, konuşma $(f=41)$ dinleme $(f=17)$ ve görsel-sunu $(f=5)$ becerileri takip etmiştir. Bu bulgulardan hareketle, özellikle dinleme ve görsel-sunu becerisine diğer becerilere oranla daha az yer verildiğini, yıllardır ihmal edilen beceri olarak kabul edilen dinleme becerisine bu programlarda da yeterince odaklanılmadığını belirtmişlerdir.

Direkci, Akbulut ve Şimşek (2019), 2018 Türkçe Dersi Öğretim Programını ve ortaokul Türkçe ders kitaplarını dijital okuryazarlık becerileri bağlamında inceledikleri çalışmada, dil becerilerindeki genel dağılımın dijital okuryazarlık becerilerinde de devam ettiğini bulmuşlardır. Ders programında dil becerileri arasında dengeli bir dağılımın olduğunu, ancak ders kitaplarında okuma becerisine yönelik etkinliklere diğer dil becerilerine oranla daha fazla yer verildiğini, bunu sırasıyla konuşma ve yazma becerilerinin izlediğini belirtmişlerdir. Dinleme becerisine yönelik ise herhangi bir etkinliğin olmadığının altını çizmişlerdir.

İlgili literatürdeki çalışmalara bakıldığında, bu çalışmaların programların genel-özel amaçlarını ele alarak betimsel analiz yoluyla yapıldığı, çalışmaların genelinin belirli programlarla sınırlı kaldığı ve dil becerilerinin (okuma, yazma, dinleme, konuşma) derinlemesine bir bakış açısıyla ele alınmadığı görülmektedir. Bu durum, ilgili alandaki bu boşluğa işaret etmektedir. Yürütülen bu çalışma ile hem alandaki bu boşluğun giderilmesi hem de gelecek araştırmalar ve araştırmacılar için alan yazına katkıda bulunulması hedeflenmektedir.

\section{YÖNTEM}

\section{Araştırma Deseni}

Cumhuriyet Dönemi Türkçe Dersi Öğretim Programlarında temel dil becerilerinin öğretilmesinde kullanılan tekniklerin belirlenmesini ve ilgili bulguların bütüncül bir şekilde yansıtılmasını amaçlayan bu çalışma, doküman incelemesi yoluyla gerçekleştirilmiştir. Araştırılan konu hakkında olgu ya da olgular içeren yazılı ve/veya görsel veri kaynaklarının bir araya getirip incelenmesi olarak tanımlanan bu yöntem, hem nicel hem de nitel araştırmalarda kullanılabilmektedir (Sönmez ve Alacapınar,2016). Özellikle eğitim bilimleri ve sosyal bilimler olmak üzere birçok alanda sıklıkla kullanılan bu yöntem farklı araştırma yöntemlerinin destekleyicisi olarak kullanılabildiği gibi bilimsel araştırmanın merkezinde yer alan bir yöntem olarak da kullanılmaktadır (Karasar,2013). Araştırmada, temel dil becerilerinin öğretiminde kullanılan tekniklerin programlara göre dağılımlarının ortaya çıkarılmasının amaçlanması nedeniyle bu yöntemin araştırmanın hedefleri ve kapsamına uygun olduğu düşünülmüştür.

\section{Veri Kaynağı}

Bu çalışma doküman incelemesine dayalı nitel araştırma yöntemi kapsamında olduğu için ankete veya ölçeğe dayalı veri elde edilmesi yoluna gidilmemiştir. Araştırmanın veri kaynağını Cumhuriyet Dönemi Türkçe Dersi Öğretim Programları (1924-2018) oluşturmaktadır. Doküman incelemesi yapılmak üzere 6 illköğretim Birinci Kademe Türkçe Dersi Öğretim Programı, 6 ilköğretim İkinci Kademe Türkçe Dersi Öğretim Programı, 7 ilköğretim (Birinci ve İkinci Kademe) Türkçe Dersi Öğretim Programı araştırmaya dâhil edilmiştir.

\section{Tablo 1. Araştırmada İncelenen Türkçe Dersi Öğretim Programları}

1340 (1924) ilk Mektep Türkçe Müfredat Programı

1926 Illk Mektep Türkçe Müfredat Programı

Ilköğretim Birinci Kademe Türkçe Dersi Öğretim

1930 Illk Mektep Türkçe Müfredat Programı

Programları

1936 Illkokul Türkçe Programı

1948 ilkokul Türkçe Programı

1968 ilkokul Türkçe Programı 
1340 (1924) Lise Birinci Devre Müfredat Programı

1929 Orta Mektep Türkçe Programı

Illköğretim İkinci Kademe Türkçe

1931-1932 Ders Senesi Tadilatı Türkçe Programı

Dersi Öğretim Programları

1938 Ortaokul Türkçe Programı

1949 Ortaokul Türkçe Programı

1962 Ortaokul Türkçe Programı

1981 Temel Eğitim Okulları Türkçe Dersi Öğretim Programı

2005 İlköğretim Türkçe Dersi Öğretim Programı (1-8)

İlköğretim (Birinci ve İkinci Kademe) Türkçe Dersi

Öğretim Programları

2015 Türkçe Dersi (1-8.sınıflar) Öğretim Programı

2017 Türkçe Dersi Öğretim Programı (1- 8.sınıflar)

2018 Türkçe Dersi Öğretim Programı (1- 8.sınıflar)

\section{Veri Toplama Süreci}

Araştırmada kullanılacak verilerin temel kaynağı olan Türkçe Dersi Öğretim Programları, güncel ders programları ve Milli Eğitim Bakanlığı'nın elektronik arşivleri taranarak elde edilmiştir. Ulaşılan veriler, sistematik ve karşılaştırmalı olarak derlenmiş, analiz ve inceleme sürecinde yorum katılmamıştır.

\section{Verilerin Analizi}

Çalışma kapsamında toplanan veriler, nitel araştırma modeline uygun biçimde içerik analizi tekniği kullanılarak incelenmiştir. Araştırma süresince, daha önceden belirlenen tematik başlıklar altında sınıflandıılan veriler sistematik biçimde analiz edilmiştir. Öncelikle elde edilecek veriler ve belge niteliğindeki dokümanlar için çalışma çerçevesi oluşturulmuştur. Bu bağlamda elde edilen veriler uygun tema altında sınıflandırılmıştır. Daha sonra verilerin tematik uygunluğuna göre temalar belirlenmiş, doğrudan alıntılar ve ifadeler kullanılarak tanımlamalar yapılmıştır. Bulguların oluşturulmasıyla birlikte ortaya çıkan bilgiler yorumlanarak sonuçlar ve öneriler oluşturulmuştur. Bu araştırmada, Cumhuriyet Dönemi Türkçe Dersi Öğretim Programlarında (1924-2018) dil becerilerini öğretmede kullanılan tekniklerden hangilerinin ele alındığının tespit edilmesi ve elde edilen sonuçların betimsel bir şekilde haritalanarak yorumlanması amaçlanmıştır. Bu sayede, Cumhuriyetin ilanıyla yeni bir paradigmaya sahip olan Türkçe Dersi Öğretim Programlarının dil becerilerinin öğretiminde izlediği tarihsel süreci de ortaya koymak bu çalışmanın önemli hedeflerinden biri olmuştur. Belirtilen amaç doğrultusunda çalışmanın problemi: “Cumhuriyet Dönemi Türkçe Dersi Öğretim Programlarında, dil becerilerinin öğretiminde kullanılan teknikler nelerdir?" şeklinde belirlenmiştir.

Bu probleme ilişkin olarak aşağıdaki alt araştırma sorularına cevap aranmıştır:

1)Cumhuriyet Dönemi Türkçe Dersi Öğretim Programlarında okuma becerisinin öğretiminde kullanılan teknikler nelerdir? 2)Cumhuriyet Dönemi Türkçe Dersi Öğretim Programlarında yazma becerisinin öğretiminde kullanılan teknikler nelerdir? 3)Cumhuriyet Dönemi Türkçe Dersi Öğretim Programlarında dinleme becerisinin öğretiminde kullanılan teknikler nelerdir? 4)Cumhuriyet Dönemi Türkçe Dersi Öğretim Programlarında konuşma becerisinin öğretiminde kullanılan teknikler nelerdir?

\section{BULGULAR}

Bu bölümde doküman incelemesi yoluyla elde edilen bulgular çalışmanın araştırma soruları doğrultusunda yorumlanarak sunulmuştur.

\section{Birinci Alt Probleme ilişkin Bulgular}

Araştırmanın birinci alt probleminde Cumhuriyet Dönemi Türkçe Dersi Programlarında okuma becerisinin öğretiminde kullanılan tekniklerin hangileri olduğu incelenmiştir. Yapılan inceleme sonucu elde edilen bulgular Tablo 2'de özet olarak sunulmuş, programlarda ilgili tekniğe yönelik ifade örnekleri bulgular bölümüne eklenmiştir. 
Tablo 2. Cumhuriyet Dönemi Türkçe Dersi Öğretim Programlarında (1924-2018) Okuma Becerisinin Öğretiminde Kullanılan Teknikler

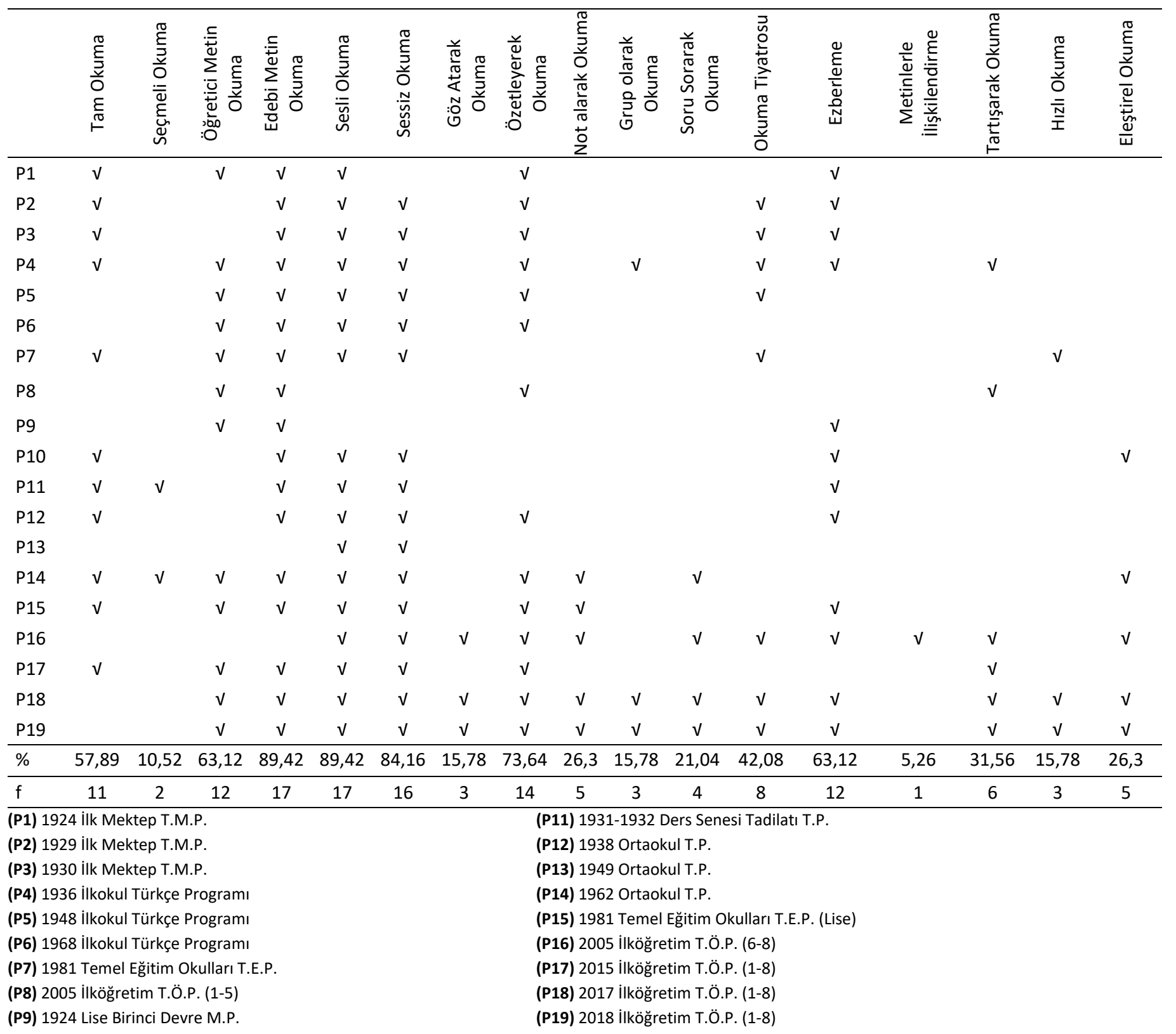

(P10) 1929 Orta mektep T.P.

Tablo 2'de de görüldüğü gibi, Cumhuriyet Dönemi Türkçe Dersi Öğretim Programlarında kullanılan okuma becerisine ilişkin öğretim teknikleri incelendiğinde; \% 89,42 oran ile "edebi metin okuma" ve "sesli okuma" tekniği ilk sırada yer almaktadır. Bu tekniği, \%84,16 ile "sessiz okuma", \%73,64 ile "özetleyerek okuma", \%63,12 ile "öğretici metin okuma " ve "ezberleme", \%57,89 ile "tam okuma", \%42,08 ile "okuma tiyatrosu" izlemektedir. Bu öğretim tekniklerini \% 31,56 ile "tartışarak okuma", \%26,03 ile "not alarak okuma ve eleştirel okuma", \%21,04 ile "soru sorarak okuma", \%15,78 ile "grup olarak okuma ve hızlı okuma", \%10,52 ile "seçmeli okuma" ve \% 5,26 ile "metinlerle ilişkilendirerek okuma" takip etmektedir. İlgili tablo incelendiğinde, 2017 ve 2018 ilıöğretim Türkçe Öğretim Programlarının içerdiği 14 farklı öğretim tekniği ile okuma becerisinin öğretiminde en fazla çeşitlilik sağlayan programlar olduğu görülmektedir. 1949 Ortaokul Türkçe Programı ise iki öğretim tekniği ile okuma becerisinin öğretimi konusunda en az öğretim tekniği çeşitliliği sağlayan program olmuştur.

Söz konusu öğretim tekniklerine ilişkin programlarda geçen bazı ifadeler aşağıda verilmiştir:

Bir parçayı, bir muharririn düşünce ve ruhunu karşısındakilere nakledecek surette cehren okumak ihtiyatlarını vermek (P11,sesli okuma)

Gazete ve dergilerin dışında çocuğa göre yazılmıs hikâye, masal, efsane, roman, piyes, şiir... gibi yazılar çocukta edebi zevkin gelişmesine hizmet eder. (P5,edebi metin okuma)

Hem okulda, hem okul dışında çocukların sessiz okumalarına bol fırsat ve olanaklar hazırlamalıdır. (P14,sessiz okuma)

Çocuklar dürüst ve selis okumaya dikkat etmekle beraber, okurken okudukları parçayı anlamaya da alıştırılmalıdır. Bunun için kıraat bittikten sonra kitaplar kapanıp mevzu, bir veya birkaç şakird tarafından anlatıl-malıdır." (P1,özetleyerek okuma) 
Talebe okuduğu manzum ve mensur parçalardan münasiplerini ezberlemelidir. (P10, ezberleme)

Hikâye edici ve bilgilendirici metinler ile şiir okutulur. (P18,öğretici metin okuma)

Öğretmen, derste okunulan parçanın genel manasını, tali fikirlerini, her paragrafın (fıkranın) esaslı fikirlerini, muhtelif cümlelerin manasını talebenin iyi anlamasına ve ifade etmesine dikkat edecektir. (P4,tam okuma)

Açık yazılmış, basit bir öyküyü küçük hareketlerle ve kişilerinin konuşmalarını canlandırarak okuyabilmek (P7,okuma tiyatrosu)

Muhtelif talebenin okumuş oldukları yazının şu veya bu noktaları hakkında derste mütalaalarını söylemeleri faydalı surette bir münakaşa mevzuu olur. (P4,tartışarak okuma)

Sesli okuma öncesinde ögrrencilere, metnin türü ve konusu hakkında bilgi verilerek not alma sırasında dikkat etmeleri gereken noktalara değinilir. Öğretmen, önemli cümleleri veya bölümleri ikinci kez okuyarak öğrencilerin dikkatini çeker. Okuma sonunda öğrencilerin aldıkları notlar değerlendirilir.(P16, not alarak okuma)

Talebe parçanın fikirleri üzerinde düşünmeli ve o parçaya karşı tenkidi bir tavır almalıdır. (P10,eleştirel okuma)

Metnin üzerinde sorular düzenlemek ve bunları cevaplandırmak (P14,soru sorarak okuma)

Bazen öğretmen talebesini muhtelif gruplara ayırarak bir gruba meselenin bir cephesi hakkında şu eserdeki parçayı, diğer gruba meselenin başka bir cephesi hakkında şu mecmuadaki yazıyı okumalarını tavsiye eder. (P4,grup olarak okuma)

Sesli, sessiz, tahmin ederek, not alarak, soru sorarak, okuma tiyatrosu ve hızlı okuma gibi yöntem ve teknikleri kullanmaları sağlanır.(P19, hizlı okuma)

\section{îkinci Alt Probleme iliş̧in Bulgular}

Araştırmanın ikinci alt probleminde Cumhuriyet Dönemi Türkçe Dersi Programlarında yazma becerisinin öğretiminde kullanılan tekniklerin hangileri olduğu incelenmiştir. Yapılan inceleme sonucu elde edilen bulgular Tablo 3’te özet olarak sunulmuş, programlarda ilgili tekniğe yönelik ifade örnekleri bulgular bölümüne eklenmiştir.

Tablo 3. Cumhuriyet dönemi Türkçe dersi öğretim programlarında yazma becerisinin öğretiminde kullanılan teknikler

\begin{tabular}{|c|c|c|c|c|c|c|c|c|c|c|c|c|c|c|}
\hline 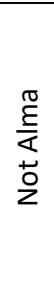 & 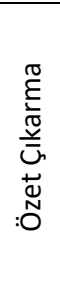 & 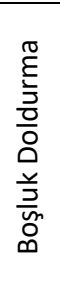 & 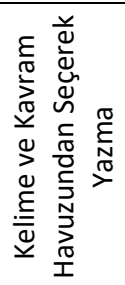 & 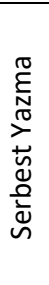 & 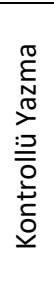 & 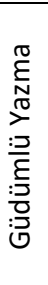 & 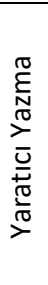 & 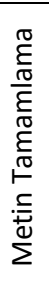 & 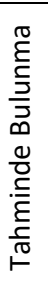 & 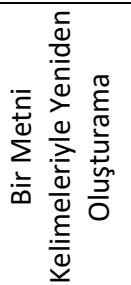 & 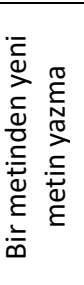 & 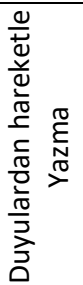 & 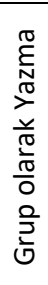 & 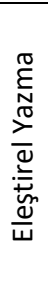 \\
\hline
\end{tabular}

\begin{tabular}{|c|c|c|c|c|c|c|}
\hline P1 & & & & & & \\
\hline P2 & & $\checkmark$ & & & & \\
\hline P3 & & $v$ & & & & \\
\hline P4 & 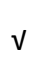 & $\checkmark$ & & & & \\
\hline P5 & & $v$ & & & & \\
\hline P6 & & $\mathrm{v}$ & & & $v$ & \\
\hline P7 & $\checkmark$ & $\checkmark$ & & & $v$ & \\
\hline P8 & & v & & & & \\
\hline P9 & & $v$ & & & & 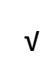 \\
\hline P10 & $v$ & & & & & $v$ \\
\hline P11 & 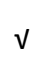 & & V & & & $\mathrm{V}$ \\
\hline P12 & & & $\mathrm{V}$ & & & \\
\hline P13 & $\checkmark$ & $v$ & & $v$ & & \\
\hline P14 & $v$ & $\checkmark$ & & $v$ & & \\
\hline
\end{tabular}

| Kastamonu Eğitim Dergisi, 2020, Vol. 28, No. 3| 


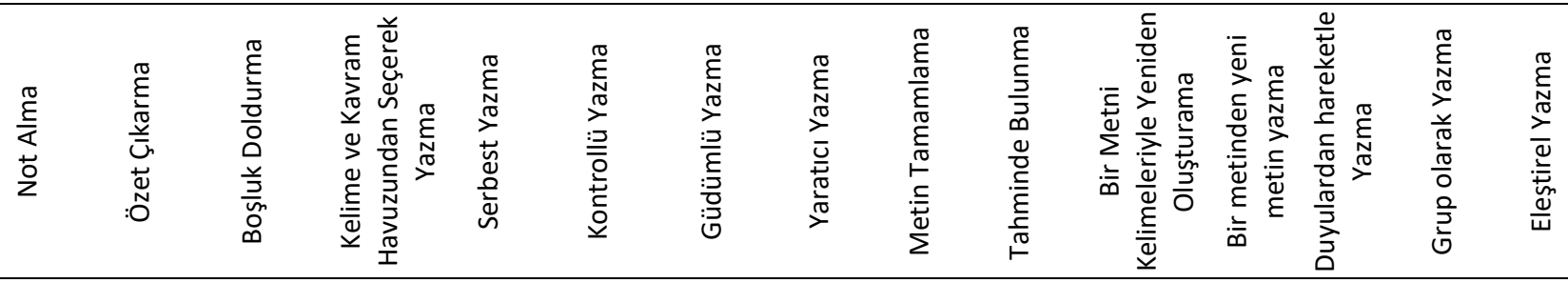

\begin{tabular}{|c|c|c|c|c|c|c|c|c|c|c|c|c|c|c|c|}
\hline P15 & & $\mathrm{V}$ & & & $\mathrm{V}$ & & & & & & & $v$ & & & \\
\hline P16 & $\mathrm{V}$ & $\mathrm{V}$ & $\mathrm{V}$ & $\mathrm{V}$ & $v$ & V & $\mathrm{V}$ & V & $\mathrm{V}$ & $\mathrm{V}$ & V & $\mathrm{V}$ & $\mathrm{V}$ & $\mathrm{V}$ & $\mathrm{V}$ \\
\hline P17 & & & & & $\mathrm{V}$ & & & & & & & & & & \\
\hline P18 & $\mathrm{V}$ & V & $V$ & $\mathrm{~V}$ & $\mathrm{~V}$ & $V$ & $\mathrm{~V}$ & $V$ & $V$ & $\mathrm{~V}$ & $\mathrm{~V}$ & V & $\mathrm{V}$ & $\mathrm{V}$ & $\mathrm{V}$ \\
\hline P19 & 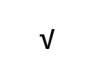 & $V$ & 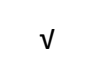 & V & $\mathrm{V}$ & $v$ & $V$ & V & 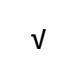 & V & V & $v$ & $\mathrm{~V}$ & V & $\mathrm{V}$ \\
\hline$\%$ & 15,78 & 52,6 & 15,78 & 15,78 & 78,9 & 15,78 & 15,78 & 15,78 & 26,3 & 15,78 & 15,78 & $\begin{array}{c}31, \\
56\end{array}$ & 15,78 & 26,3 & 31,56 \\
\hline$f$ & 3 & 10 & 3 & 3 & 15 & 3 & 3 & 3 & 5 & 3 & 3 & 6 & 3 & 5 & 6 \\
\hline
\end{tabular}

(P1) 1924 ilk Mektep T.M.P.

(P2) 1929 ilk Mektep T.M.P.

(P11) 1931-1932 Ders Senesi Tadilatı T.P.

(P3) 1930 ilk Mektep T.M.P.

(P4) 1936 İlkokul Türkçe Programı

(P5) 1948 illkokul Türkçe Programı

(P6) 1968 ilkokul Türkçe Programı

(P7) 1981 Temel Eğitim Okulları T.E.P.

(P8) 2005 İlköğretim T.Ö.P. (1-5)

(P9) 1924 Lise Birinci Devre M.P.

(P12) 1938 Ortaokul T.P.

(P13) 1949 Ortaokul T.P.

(P14) 1962 Ortaokul T.P.

(P15) 1981 Temel Eğitim Okulları T.E.P. (Lise)

(P16) 2005 ilköğretim T.Ö.P. (6-8)

(P17) 2015 İlköğretim T.Ö.P. (1-8)

(P18) 2017 İlköğretim T.Ö.P. (1-8)

(P19) 2018 ilköğretim T.Ö.P. (1-8)

(P10) 1929 Orta mektep T.P.

Tablo 3’te görüldüğü gibi, araştırmaya dâhil edilen Cumhuriyet Dönemi Türkçe Dersi Öğretim Programlarında kullanılan yazma becerisine yönelik öğretim teknikleri incelendiğinde; \% 73,64'lük oran ile "serbest yazma" tekniği ilk sırada yer almaktadır. Ele alınan 19 öğretim programının 14'ünde bu öğretim tekniği kullanılmıştır. Söz konusu tekniği \%52,6 ile "özet çıkarma”, \% 31,6 'ile "bir metinden yeni bir metin" ve " eleştirel yazma", \%26,3 ile "metin tamamlama" ve "grup olarak yazma" teknikleri izlemektedir. Ele alınan programlar içerisinde $\% 15,78^{\prime}$ lik oran sahip diğer öğretim teknikleri ise şunlardır: not alma, boşluk doldurma, kelime veya kavram havuzundan yazma, kontrollü, güdümlü, yaratıcı, tahminde bulunma, bir metni kelimeleriyle yeniden oluşturma ve duyulardan hareketle yazma. İgili tablo detaylı bir şekilde incelendiğinde program bazında hangi öğretim tekniklerinin kullanıldığını görmek mümkündür. Yazma becerisinin geliştirilmesine yönelik öğretim tekniklerine ait programlarda geçen ifadeler incelendiğinde, yapılandırmacı yaklaşım temelinde hazırlanan 2005 Türkçe Dersi Programı́na dek yazma becerisinin geliştirilmesine yönelik öğretim tekniklerinin kullanımında belirli teknikler (özet çıkarma, serbest yazma, metin tamamlama, eleştirel yazma, grup olarak yazma, metin tamamlama) dışına çıkılmadığı görülmüştür. 2005 Türkçe Dersi Öğretim Programında ise dinleme becerisinin geliştirilmesine yönelik 15 farklı öğretim tekniği kullanılmıştır. Söz konusu teknikler 2017 ve 2018 Türkçe Dersi Öğretim Programlarında da kullanılmış, yazma becerisinin öğretiminde geniş bir öğretim tekniği yelpazesinden yararlanılmıştır.

Çalışmaya dâhil edilen programlarda yukarıda bahsi geçen tekniklere ilişkin bazı ifadeler aşağıda verilmiştir:

Tahrir (yazma) vazifelerinin yapılmasında çocuklara mümkün mertebe serbesti vermelidir. Her bir vazife için plan yapmaya hacet yoktur. Ancak yeni bir tahrir numunesi için plan verilebilir. ( $P 2$, serbest yazma)

Ayrıca, eğlenmek ve bilgi edinmek için yazma, sorgulayıcı, ikna edici, betimleyici ve serbest yazma gibi tür, yöntem ve teknikler de verilmektedir.(P8, serbest yazma)

Öğretmen, ilkokuldan gelen öğrencilerin yazma kişiliklerini belirtmeye çalışacak ve ödevleri inceleyerek edindiği kanılardan, onların yazma eğilimlerine uygun yazma konuları vermek hususunda yaralanacaktır. Özellikle serbest yazma çalışmalarının bu konuda çok yararlı sonuçları görülmektedir. (P14, serbest yazma)

Okuduğu bir kitabı, izlediği bir filmi tanıtabilmek, özetleyebilmek; o kitap ya da film üzerindeki düşüncelerini belirtebilmek (P15, özet çıkarma)

Not alma, özet çıkarma, eleştirel, yaratıcı, serbest, kelime ve kavram havuzundan seçerek yazma, bir metinden ve duyulardan hareketle yazma gibi yöntem ve tekniklerin kullanılması sağlanır.(P18-P19, özet çıkarma)

Küçük bir hikâye ve bazı fıkraları piyes haline çevrilebilmek (P14, bir metinden hareketle yeni bir metin oluşturma)

Öğrencilere düşünceye veya olaya dayalı bir metin verilerek okutulur/dinletilir. Metindeki düşünce ve olayları kavrayan öğrenciler "Ben olsaydım nasıl yazardım?" düşüncesinden hareketle metni kendi ifadeleriyle yeniden kurgularlar. (P16, bir metinden hareketle yeni bir metin oluşturma)

Muhtelif üslupta yazılmış eserlere dair bazı mülahaza ve tenkit tecrübelerinde bulunmak da faydalı olur.(P9, eleştirel yazma) 
Kendisini alakadar eden edebi, ilmi, ticari bir mevzu üzerine tetkik ve tetebbüde bulunarak okuyanlara alaka verecek bir şekilde yazmak (P10, eleştirel yazma)

... eleştirel, yaratıcı, serbest, kelime ve kavram havuzundan seçerek yazma, bir metinden ve duyulardan hareketle yazma gibi yöntem ve tekniklerin kullanılması sağlanır.(P18-P19, eleştirel yazma)

Muallim tarafından talebeye karşı yarıya kadar okutulan veya anlatılan bir hikâyenin ötesini uydurmak veya baştanbaşa okunan yahut anlatılan bir hikâyeye zeyil yazmak (P11, metin tamamlama)

...herhangi bir konuya yönelik bir metin okutulur veya dinletilir. Öğrencilerden okurken veya dinlerken/izlerken önemli noktaları not almaları istenir.(P16, not alma)

\section{Üçüncü Alt Probleme ilişkin Bulgular}

Araştırmanın üçüncü alt probleminde Cumhuriyet Dönemi Türkçe Dersi Programlarında dinleme becerisinin öğretiminde kullanılan tekniklerin hangileri olduğu incelenmiştir. Yapılan inceleme sonucu elde edilen bulgular Tablo 4'te özet olarak sunulmuş, programlarda ilgili tekniğe yönelik ifade örnekleri bulgular bölümüne eklenmiştir.

Tablo 4. Cumhuriyet Dönemi Türkçe Dersi Öğretim Programlarında Dinleme Becerisinin Öğretiminde Kullanılan Teknikler

\begin{tabular}{|c|c|c|c|c|c|c|c|c|c|c|}
\hline 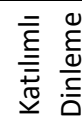 & 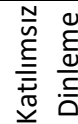 & $\stackrel{+}{\circ}$ & 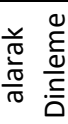 & 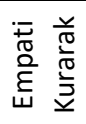 & $\frac{\stackrel{d}{\varepsilon}}{\frac{d}{c}}$ & 은 & 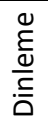 & 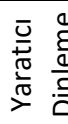 & $\stackrel{\bar{u}}{\mathscr{N}}$ & 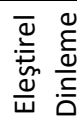 \\
\hline
\end{tabular}

P1

$\mathrm{P} 2$

P3

P4

P5

P6

P7

V

P8

p9

P10

P11

P12

P13

P14

P15

P16

V

V

V

P17 $\quad v$

\begin{tabular}{|c|c|c|c|c|c|c|c|c|}
\hline P18 & $v$ & $v$ & $V$ & $\mathrm{~V}$ & $\mathrm{~V}$ & $v$ & $V$ & $\mathrm{~V}$ \\
\hline P19 & $v$ & $\mathrm{~V}$ & $\mathrm{~V}$ & $\mathrm{~V}$ & $\mathrm{~V}$ & $\mathrm{~V}$ & $\mathrm{~V}$ & $\mathrm{~V}$ \\
\hline$\%$ & 15,78 & 31,56 & 21,04 & 15,78 & 10,52 & 15,78 & 15,78 & 21,04 \\
\hline$f$ & 3 & 6 & 4 & 3 & 2 & 3 & 3 & 4 \\
\hline
\end{tabular}

(P1) 1924 illk Mektep T.M.P.

(P2) 1929 ilk Mektep T.M.P.

(P11) 1931-1932 Ders Senesi Tadilatı T.P.

(P3) 1930 ilk Mektep T.M.P.

(P12) 1938 Ortaokul T.P.

(P4) 1936 illkokul Türkçe Programı

(P5) 1948 İlkokul Türkçe Programı

(P13) 1949 Ortaokul T.P.

(P6) 1968 İlkokul Türkçe Programı

(P14) 1962 Ortaokul T.P.

(P15) 1981 Temel Eğitim Okulları T.E.P. (Lise)

(P7) 1981 Temel Eğitim Okulları T.E.P

(P16) 2005 İlköğretim T.Ö.P. (6-8)

(P8) 2005 İlköğretim T.Ö.P. (1-5)

(P17) 2015 İlköğretim T.Ö.P. (1-8)

(P9) 1924 Lise Birinci Devre M.P.

(P18) 2017 ilköğretim T.Ö.P. (1-8)

(P10) 1929 Orta mektep T.P.

(P19) 2018 ilköğretim T.Ö.P. (1-8) 
Tablo 4'te Cumhuriyet Dönemi Türkçe Dersi Öğretim Programlarında dinleme becerisinin öğretiminde kullanılan öğretim tekniklerine ilişkin bulgular verilmiştir. ilgili tabloda da görüldüğü gibi ele alınan programlarda en çok kullanılan dinleme tekniği \%31,56 ile "katılımsız dinleme" olmuştur. Bu tekniği, \%21,04 ile "not alarak ve eleştirel dinleme"; \%15,78 ile "katılımlı, empati kurarak, yaratıcı ve seçici dinleme" ve \%10,52 ile de "grup halinde dinleme” öğretim tekniği izlemiştir. İlgili tabloda da görüldüğü gibi 1981 Temel Eğitim Okulları Türkçe Dersi Öğretim Programı́na kadar hiçbir öğretim programında dinleme becerisinin geliştirilmesine yönelik herhangi bir öğretim tekniğine dair bir ifade yer almazken, bu programdan itibaren farklı öğretim tekniklerine (katılımsız, not alarak, eleştirel dinleme) yer verildiği görülmüştür. Yapılandırmacı yaklaşım temel alınarak hazırlanan 2005 Türkçe Dersi Öğretim Programı́ndan itibaren ise dinleme becerisinin geliştirilmesine yönelik öğretim teknikleri o zamana kadar ki en fazla çeşitliliğe ulaşmıştır. İlgili programda 7 farklı öğretim tekniğinden yararlanarak dinleme becerisinin geliştirilmesi ve öğretilmesi sağlanmıştır. 2017 ve 2018 Türkçe Dersi Öğretim Programlarında ise kullanılan öğretim tekniklerinin sayısı 8'e yükselmiştir.

Bu bulgulara destekleyici bazı ifadeler aşağıda verilmiştir:

Bir münazarayı, açık oturumu vb. ni dinleyip izleyebilmek (söz verilirse) yöntemine uygun soru sormak (P7, katılımsız dinleme)

Dinlenilen metnin bir süreçten mi bahsettiği, yoksa bir açıklama mı getirdiği belirlenir. Metnin türüne ve metinden elde etmek istenilenlere uygun olarak zihinde "Kim, ne, nereye, ne zaman, nasıl?" gibi sorulara cevap bulmaları için öğrenciler yönlendirilir.(P16,katılımsız dinleme)

Dinlediklerindeki/izlediklerindeki ana fikri ve ana fikri destekleyen düşünceleri belirler. (P17,katılımsız dinleme)

Katılımlı, katılımsız, grup hâlinde ve not alarak dinleme gibi yöntem ve teknikleri uygulamaları sağlanır. (P18-P19,öğretim teknikleri)

35-40 dakikalık bir konuşmayı, konferansı vb. ni dinleyebilmek ve ilginç bölümlerinden not alabilmek (P15, not alarak dinleme)

Ögrrencilerden dinleme/izleme amaçlarına göre notlar almaları istenir. Not alınırken dikkat etmeleri gereken noktalar (ana fikrin, önemli ifadelerin, güzel sözlerin not alınması; özgün ifadelerin kullanılması vb.) hatırlatılır. Öğrencilere not alabilecekleri çalışma kâğıtları verilir. (P16, not alarak dinleme)

Seçici, yaratıcı, eleştirel, empati kurarak, not alarak dinleme gibi yöntem ve teknikleri uygulamaları sağlanır. (P18-P19,öğretim teknikleri)

Okunan bir kitap, dinlenen müzik parçası, gezilen bir sergi, izlenen bir film, bir oyun, bir maç vb. üzerine açıklamalarda, eleştirmelerde bulunabilme; yargıya varabilme (P15, eleştirel dinleme)

Sunulan bilginin konuşmacının kişisel duygu ve düşüncelerini mi yansıttığı, yoksa bilimsel verilere ve gözlemlere mi dayandığı hızlı bir şekilde analiz edilmelidir. (P16, eleştirel dinleme)

Dinleyici, konuyu daha iyi anlamak, istekte bulunmak veya karmaşık bir probleme çözüm sunmak amacıyla da konuşmacıya sorular sorabilir. Böyle durumlarda not alınarak veya araya girilerek "Söylediklerinizi tam olarak anlayamadım. Daha açık söyler misiniz? "gibi açıklama soruları sorulabilir.(P16, katılımlı dinleme)

Öğrencilerden konuşmacının veya dinlediklerindeki/izlediklerindeki varlık ve şahıslardan birinin yerine kendilerini koyarak olayları, duygu ve düşünceleri anlamaları istenir. Bu yöntemle yapılan dinleme/izleme diğer kişi ile aynı fikri paylaşma anlamına gelmez.(P16, empati kurarak dinleme)

\section{Dördüncü Alt Probleme ilişkin Bulgular}

Araştırmanın dördüncü alt probleminde Cumhuriyet Dönemi Türkçe Dersi Programlarında konuşma becerisinin öğretiminde kullanılan tekniklerin hangileri olduğu incelenmiştir. Yapılan inceleme sonucu elde edilen bulgular Tablo 5 'te özet olarak sunulmuş, programlarda ilgili tekniğe yönelik ifade örnekleri bulgular bölümüne eklenmiştir.

Tablo 5. Cumhuriyet dönemi Türkçe dersi öğretim programlarında konuşma becerisinin öğretiminde kullanılan teknikler

\begin{tabular}{|c|c|c|c|c|c|c|c|c|c|}
\hline & 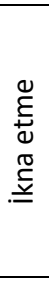 & 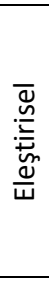 & $\begin{array}{l}\overline{\bar{E}} \\
\underline{\underline{\underline{E}}} \\
\underline{\bar{T}}\end{array}$ & $\begin{array}{l}\stackrel{\sigma}{E} \\
\stackrel{\frac{\pi}{m}}{\frac{\pi}{\sigma}} \\
\mapsto\end{array}$ & $\begin{array}{l}\frac{y}{0} \\
\frac{0}{0} \\
\frac{0}{J} \\
\underline{y} \\
\frac{\pi}{0} \\
\frac{0}{E} \\
\frac{E}{U}\end{array}$ & 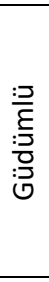 & 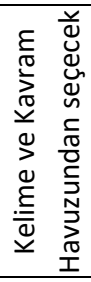 & 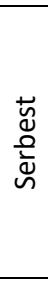 & $\frac{\bar{U}}{\frac{\pi}{\pi}}$ \\
\hline \multicolumn{10}{|l|}{ P1 } \\
\hline P2 & & & $\mathrm{V}$ & & & & & $\mathrm{V}$ & \\
\hline P3 & & & $\mathrm{V}$ & & & & & $\mathrm{V}$ & \\
\hline P4 & & $\mathrm{V}$ & & & & & & & \\
\hline P5 & & & & $\mathrm{V}$ & & & & & \\
\hline P6 & & & & $\mathrm{V}$ & $\mathrm{V}$ & & & $\mathrm{V}$ & \\
\hline P7 & & & & & & & & $\mathrm{V}$ & \\
\hline P8 & $\mathrm{V}$ & $\mathrm{V}$ & & & & & & $\mathrm{V}$ & \\
\hline \multicolumn{10}{|l|}{ P9 } \\
\hline \multicolumn{10}{|l|}{ P10 } \\
\hline \multicolumn{10}{|l|}{ P11 } \\
\hline P12 & & & & & & & & & \\
\hline
\end{tabular}




\begin{tabular}{|c|c|c|c|c|c|c|c|c|c|}
\hline & 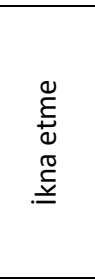 & 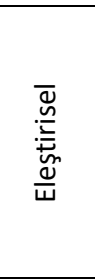 & $\begin{array}{l}\overline{\bar{\xi}} \\
\underline{\underline{\underline{E}}} \\
\underline{\underline{\pi}}\end{array}$ & 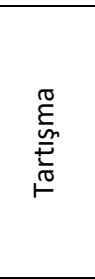 & 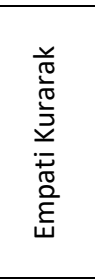 & 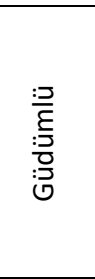 & 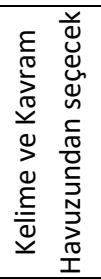 & 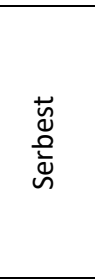 & $\begin{array}{l}\overline{\mathrm{v}} \\
\frac{\pi}{\tilde{N}} \\
\stackrel{\bar{\sigma}}{\nu}\end{array}$ \\
\hline P13 & & & & $v$ & $v$ & & & $v$ & $\mathrm{~V}$ \\
\hline P14 & & & $\mathrm{V}$ & & v & & & v & v \\
\hline P15 & & v & & & & & & $v$ & v \\
\hline P16 & v & v & $\mathrm{V}$ & v & v & v & v & $v$ & v \\
\hline P17 & & & & & & & & $v$ & \\
\hline P18 & v & v & v & v & v & v & v & $v$ & v \\
\hline P19 & v & $v$ & v & v & v & v & v & $v$ & $v$ \\
\hline$\%$ & 21,04 & 31,56 & 31,56 & 31,56 & 31,56 & 15,78 & 15,78 & 63,12 & 31,56 \\
\hline$f$ & 4 & 6 & 6 & 6 & 6 & 3 & 3 & 12 & 6 \\
\hline
\end{tabular}

(P1) 1924 ilk Mektep T.M.P.

(P2) 1929 ilk Mektep T.M.P.

(P12) 1938 Ortaokul T.P.

(P3) 1930 ilk Mektep T.M.P.

(P13) 1949 Ortaokul T.P.

(P4) 1936 illkokul Türkçe Programı

(P14) 1962 Ortaokul T.P.

(P5) 1948 ilkokul Türkçe Programı

(P6) 1968 ilkokul Türkçe Programı

(P7) 1981 Temel Eğitim Okulları T.E.P.

(P15) 1981 Temel Eğitim Okulları T.E.P. (Lise)

(P8) 2005 İlköğretim T.Ö.P. (1-5)

(P16) 2005 Illköğretim T.Ö.P. (6-8)

(P17) 2015 ilköğretim T.Ö.P. (1-8)

(P18) 2017 ilköğretim T.Ö.P. (1-8)

(P9) 1924 Lise Birinci Devre M.P.

(P19) 2018 Illköğretim T.Ö.P. (1-8)

(P10) 1929 Orta mektep T.P.

Tablo 5'te Cumhuriyet Dönemi Türkçe Dersi Öğretim Programlarında konuşma becerisinin öğretiminde kullanılan öğretim tekniklerine ilişkin bulgular gösterilmektedir. Mevcut tablodaki bulgulara baktığımızda ele alınan programlarda konuşma becerisinin öğretiminde en çok kullanılan tekniğin \% 63,12'lik oran ile "serbest konuşma" tekniği olduğu görülmektedir. Bu tekniği \%31,56 ile "eleştirisel, katılımlı, tartışma, empati kurarak ve yaratıcı konuşma" öğretim teknikleri; \%21,04 ile "ikna etme" öğretim tekniği ve \%15,78 ile "güdümlü ve kelime ve kavram havuzundan seçerek konuşma” öğretim teknikleri izlemektedir. Konuşma becerisinin öğretimi konusunda 2005 Türkçe Dersi Öğretim Programına kadar en fazla öğretim tekniği çeşitliliği sağlayan programlar 1949 ve 1962 Ortaokul Türkçe Programları olmuştur. Söz konusu programlarda dört farklı öğretim tekniğinden yararlanılarak konuşma becerisinin geliştirilmesi amaçlanmıştır. 2005 Türkçe Dersi Öğretim Programı́nda ise 9 farklı öğretim tekniğinden yararlanılmıştır. Birbirinin devamı/güncellemesi niteliğindeki 2017 ve 2018 programlarında da aynı sayıda öğretim tekniğinden yararlanarak konuşma becerisinin geliştirilmesi hedeflenmiştir.

İncelenen programlarda bu bulgulara ilişkin geçen bazı ifadeler aşağıda verilmiştir:

Kıraat kitabında okutulan bir parçanın meali serbestçe anlattırılacaktır. (P2, serbest konuşma)

Öğrencilere karagöz, kukla oyunları oynattırmak ve yazılı piyesler temsil ettirmek de serbest konuşmayı geliştirecek birer eğitim yoludur. (P6, serbest konuşma)

Herhangi bir konu üzerinde bir topluluk karşısında tekrarlara düşmeden ve yanlışlık yapmadan 5-10 dakika konuşabilme (P15, serbest konuşma)

Öğrenciler seçtikleri konu hakkındaki duygu, düşünce ve hayallerini anlatırlar. Öğrencilere kendilerini ifade etme fırsatı vermek için haftalık ders saatinin bir kısmı serbest konuşmaya ayrılmalıdır.(P16, serbest konuşma)

Serbest, güdümlü, yaratıcı, hafızada tutma tekniği ve kelime kavram havuzundan seçerek konuşma gibi yöntem ve tekniklerin kullanılması sağlanır. (P19, serbest konuşma)

Muhtelif talebenin okumuş oldukları yazının şu veya bu noktaları hakkında derste mütalaalarını söylemeleri fay-dalı surette bir münakaşa mevzuu olur.(P4, eleştirel konuşma)

Okunan bir kitap, dinlenen müzik parçası, gezilen bir sergi, izlenen bir film, bir oyun, bir maç vb. üzerine açıklamalarda, eleştirmelerde bulunabilme; yargıya varabilme (P15, eleştirel konuşma)

Konudan ayrılmamak ve başkaları hakkında nezaketsizlikte bulunmamak şartıyla bir tartışmaya katılabilmek, gerekince bir mesele hakkında fikrini ve bilgisini ileri sürmek (P14, katılımlı konuşma)

Yaratıcı, güdümlü, empati kurma, tartışma, ikna etme ve eleştirel konuşma gibi yöntem ve tekniklerinin kullanılması sağlanır. (P19, öğretim teknikleri)

Önce birinin söz açmasıyla başlayan konuşma iyi idare edilirse, sınıfta canlı, ateşli ve faydalı konuşmalarla münakaşalara yol açar.(P5, tartışma)

Konuşma yeteneğinin iyi gelişmesinde karşılıklı konuşma, anlatma, münakaşa ve hikâye etme şekillerinden başka dramatizasyon çalışmalarııın da önemli rolü vardır. (Öğrencilerin kendilerini, dinledikleri veya okudukları olaylardaki şahısların yerine koymaları, onların hareketlerini temsil etmeleri) (P13-P14, empati kurarak)

| Kastamonu Eğitim Dergisi, 2020, Vol. 28, No. 3| 
Öğretmen tarafından belli bir konu seçilerek sınıfın gündemine alınır. Konu hakkında öğrenciler bilgilendirilir. Sınıfta konuyla ilgili beyin fırtınası yapılır. Birkaç öğrenci seçilerek konu hakkındaki duygu, düşünce ve hayallerini iki dakika içinde ifade etmeleri sağlanır.(P16,güdümlü konuşma)

\section{SONUÇ, TARTIŞMA VE ÖNERILER}

Bu çalışmada, Cumhuriyet Dönemi Türkçe Dersi Öğretim Programlarında (1924-2018) temel dil becerilerinin (okuma, yazma, dinleme/izleme, konuşma) öğretiminde kullanılan tekniklerin kullanım durumları incelenmiştir. İçerik analizi yapılarak incelenen 19 öğretim programından elde edilen bulgulara göre aşağıdaki sonuçlara ulaşılmıştır:

Araştırmanın ilk probleminin de hedef noktası olan okuma becerisinin öğretiminde kullanılan tekniklere ilişkin bulgular incelendiğinde, programların büyük çoğunluğunda $(\% 89,42)$ edebi metin okuma ve sesli okuma tekniğinin okuma becerisinin öğretiminde en sık kullanılan teknikler olduğu bulunmuştur. Bu tekniğe oldukça yakın değerlere sahip sessiz okuma (\%84,16) tekniğinin de öğretim programlarında okuma becerisinin öğretiminde en sık başvurulan diğer bir teknik olduğu görülmüştür. Ele alınan 19 öğretim programında söz konusu üç tekniğin yanı sıra sıklıkla başvurulan diğer teknikler ise özetleyerek okuma (\%73,64), öğretici metin okuma ve ezberleme $(\% 63,12)$, tam okuma $(\% 57,89)$ ve okuma tiyatrosudur $(\% 42,08)$. Her ne kadar bu tekniklerde olduğu gibi yüksek kullanım sıklığına sahip olmasa da tartışarak okuma (\%31,56), not alarak okuma ve eleştirel okuma $(\% 26,03)$, soru sorarak okuma $(\% 21,04)$, grup olarak okuma ve hızlı okuma $(\% 15,78)$, seçmeli okuma $(\% 10,52)$ ile metinlerle ilişkilendirerek okuma $(\% 5,26)$ okuma becerisinin öğretiminde kullanılan diğer teknikler olmuştur. Bu bulgulardan hareketle, Türkçe Dersi Öğretim Programlarının özel amaçlarından birisi olan "Türk ve dünya kültür ve sanatına ait eserler aracılığıyla estetik ve sanatsal değerleri fark etmelerinin ve benimsemelerinin sağlanması” (MEB, 2018, s.8) maddesinde belirtilen hedefe ulaşmak amacıyla öğretim programlarının şekillendirildiği sonucuna ulaşabilirsiniz. Öğrencilerin ilgili metindeki anlama dikkat etmesinden ziyade doğru ve güzel telaffuza, vurgu ve tonlamaya dikkat etmesi nedeniyle okuma becerisinin öğretiminde sesli okumaya kıyasla sessiz okumanın tercih edilmesi durumunu dikkate aldığımızda, bu araştırmada elde edilen bulguların pratikte yaygın olarak tercih edilmediği görülmektedir.

Araştırmanın ikinci alt probleminin odak noktası olan yazma becerisinin öğretiminde kullanılan tekniklere ilişkin bulgulara bakıldığında, Cumhuriyet Dönemi Türkçe Dersi Öğretim Programlarında yazma becerisinin öğretiminde en sık başvurulan tekniğin serbest yazma tekniği $(\% 73,64)$ olduğu bulunmuştur. Ele alınan 19 öğretim programının 14'ünde yazma becerisinin öğretiminde başvuru tekniği olarak kullanılan bu tekniğinin yanı sıra özet çıkarma tekniği $(\% 52,6)$ de öğretim programlarının önemli bir bölümünde kullanılan diğer teknik olmuştur. Öğretim programlarında yazma becerisinin öğretiminde bu iki tekniğe ek olarak sıklıkla tercih edilen tekniklerin bir metinden yeni bir metin ve eleştirel yazma $(\% 31,6)$, metin tamamlama ve grup olarak yazma teknikleri $(\% 26,3)$ olduğu görülmüştür. Öğretim programlarının genelinde ele alınmasa da yazma becerisinin öğretiminde kullanılan diğer tekniklerin not alma, boşluk doldurma, kelime veya kavram havuzundan yazma, kontrollü, güdümlü, yaratıcı, tahminde bulunma, bir metni kelimeleriyle yeniden oluşturma ve duyulardan hareketle yazma teknikleri olduğu yapılan içerik analizinde ortaya çıkmıştır. Çalışmanın bu bulgusu, Temizkan ve Atasoy'un (2014) 1924-2005 yılları arasındaki 5 Türkçe dersi öğretim programında yazma becerisinin ele alınış şeklini inceleyen çalışmasından elde ettiği sonuçlarla benzerlik göstermektedir. Söz konusu çalışmada, araştırmacılar ele aldıkları programların içerdiği eğitim-öğretim etkinlikleri ve amaçları bakımından çağdaş program geliştirme anlayışının dışında bir bakış açısıyla hazırlandığını öne sürmüştür. Nitekim çalışmamızdan elde edilen bulgulara baktığımızda söz konusu programlarda (1924-2005 arasındaki) yazma becerisinin öğretiminde altı farklı öğretim tekniğine yer verildiği, ancak bu teknikler arasında en yaygın olarak serbest yazma tekniğinin kullanıldığı sonucuna ulaşılmıştır. Ele alınan 15 farklı öğretim tekniğinin sadece 6 tanesinin kullanılması Temizkan ve Atasoy'un (2014) elde ettiği bulguları destekler niteliktedir.

Üçüncü alt araştırma sorusunda cevap aranılan “Cumhuriyet Dönemi Türkçe Dersi Öğretim Programlarında dinleme becerisinin öğretiminde kullanılan teknikler nelerdir? sorusuna ilişkin bulgular ele alındığında, öğretim programlarının önemli bir bölümünde dinleme becerisinin öğretimine ilişkin tekniklerle ilgili herhangi bir ifadeye rastlanılmamıştır. Öğretim programlarının genelindeki durum bu şekilde iken bazı programlar dinleme becerisinin öğretimine ilişkin ifadelere yer ayırmıştır. Bu ifadelere bakıldığında katılımsız dinleme tekniği \%31, 56'ık oran ile kullanılan öğretim teknikleri arasında en çok tercih edilen teknik olmuştur. Not alarak dinleme ve eleştirisel dinleme teknikleri (\%21,04) ile özellikle 2005, 2017 ve 2018 Türkçe Dersi Öğretim Programlarında dinleme becerisinin öğretiminde başvurulan teknikler olan katılımlı, empati kurarak, yaratıcı ve seçici dinleme teknikleri $(\% 15,78)$ ve grup halinde dinleme $(\% 10,52)$ tekniği dinleme becerisinin öğretiminde başvurulan diğer teknikler olmuştur. 2005 ilköğretim Türkçe dersi öğretim programına kadar programların önemli bir bölümünde dinleme becerisine ait herhangi bir öğretim tekniğine yer verilmemesi Balcı, Coşkun ve Tamer'in (2012) çalışmasında da belirttiği gibi dinleme becerisi ihmal edilen ve yeterince odaklanılmayan bir beceri olarak öne çıkmıştır. Buna benzer olarak, Melanlıoğlu (2012) de çalışmasında dinleme becerisinin Türkçe Dersi Öğretim Programlarında göz ardı edilen bir beceri olduğunu açıkça ifade etmiş, bu becerinin geliştirilmesine yönelik önerilerde bulunmuştur.

Araştırmanın dördüncü ve sonuncu alt probleminde cevap aranan konuşma becerisinin öğretiminde kullanılan tekniklere ilişkin bulgulara bakıldığında serbest konuşma tekniğinin \%63, 12'lik oran ile incelenen öğretim programları içerisinde en çok tercih edilen teknik olduğu görülmüştür. Serbest konuşma tekniği kadar sıklıkla kullanılmasa da eleştirisel, katılımlı, tartışma, empati kurarak, yaratıcı konuşma $(\% 31,56)$, ikna etme $(\% 21,04)$, güdümlü ve kelime ve kavram havuzundan seçerek konuşma tekniği $(\% 15,78)$ öğretim programlarında konuşma becerisinin öğretiminde kullanılan diğer teknikler olmuştur. Bu bulgu, Arhan (2007) tarafından 
yürütülen çalışmanın sonuçlarını destekleyici özelliğe sahiptir. İlgili çalışmaya katılan katılımcılar (öğretmenler) mevcut Türkçe programının konuşma eğitimi konusunda yetersiz olduğunu ifade etmiştir.

Araştırmanın bulgularından hareketle program geliştiricilere yeni hazırlayacakları programlarda dil eğitiminde an-lama ve anlatma becerilerinin önemini göz önünde bulundurarak her bir dil becerisine eşit ağırlık verilmesi gerektiği, anlama becerilerinden biri olan okuma becerisinin öğretiminde kullanılan öğretim tekniklerindeki çeşitliliğin diğer dil becerilerine da yayılması hususunda daha özenli davranmaları önerilmektedir. Ayrıca, uygulayıcıların (öğretmenlerin) önceki programlardaki kısıtlı öğretim tekniklerinin etkisinden kurtularak dil becerilerinin öğretiminde öğretim tekniği çeşitliliği sağlamaları halinde öğrencilerin öğrenmelerini kolaylaştırabilecekleri düşünülmektedir. Benzer konuda çalışma yapmayı planlayan araştırmacıların Milli Eğitim Bakanlığı bünyesinde üretilen ders kitaplarını inceleyerek programlarda geçen öğretim tekniklerinin ne ölçüde ders kitaplarında yansıtıldığına dair çalışma yapmaları resmin bütününe ortaya koyma bakımından eğitim sistemimize oldukça faydalı olacaktır.

\section{KAYNAKÇA}

Akpınar, B. ve Gezer, B.(2010). Öğrenen merkezli yeni eğitim yaklaşımlarının öğrenme-öğretme sürecine yansımaları. Dicle Üniversitesi Ziya Gökalp Eğitim Fakültesi Dergisi, 14,1-12.

Anıl, D., Özer Özkan, Y. ve Demir, E. (2015). PISA 2012 araştırması ulusal nihai rapor. T.C. Milli Eğitim Bakanlığı Ölçme, Değerlendirme ve Sınav Hizmetleri Genel Müdürlügü: Ankara.

Arhan, S. (2007) Öğretmen görüşlerine göre ilköğretim okulları ikinci kademede konuşma eğitimi (Ankara İli Örneği). (Yüksek lisans tezi). Gazi Üniversitesi /Eğitim Bilimleri Enstitüsü, Ankara.

Aslan, E. (2011). Türkiye Cumhuriyeti’nin İlkokullarda İzlediği illk Öğretim Programı: “1924 İlk Mektepler Müfredat Programı”. İlköğretim Online, 10(2), 717-734

Balcı, A., Coşkun E. ve Tamer, M. (2012) Cumhuriyet dönemi Türkçe dersi öğretim programlarının genel amaçları bakımından değerlendirilmesi. Dil ve Edebiyat Eğitimi Dergisi, 1(1), 1-13.

Direkçi, B., Akbulut, S., Şimşek, B. (2019). Türkçe dersi öğretim programı (2018) ve ortaokul Türkçe ders kitaplarının dijital okuryazarlık becerileri bağlamında incelenmesi. Avrasya Uluslararası Araştırmalar Dergisi, 7 (16) , 797-813.

Girgin, Y. (2011). Cumhuriyet Dönemi (1929-1930, 1949,1981) Ortaokul Türkçe Öğretimi Programlarının İçerik, Genel ve Özel Amaçlarıyla Karşılaştırmalı Gelişim Düzeyi. Adnan Menderes Üniversitesi Eğitim Fakültesi Eğitim Bilimleri Dergisi, 2(1), 11-26.

Göçer, A. (2015). Temel dil becerilerinin geliştirilmesinde dil bilgisi öğrenme alanının yeri, işlevi ve öğretimi: bütünlük ilkesi ve tümevarım yöntemi ekseninde tematik bir yaklaşım. Eğitim ve Öğretim Araştırmaları Dergisi, 4(1), 233-242.

Güneş, F. (2014). Türkçe öğretiminde günümüz gelişmeleri ve yapılandırıcı yaklaşım. Mustafa Kemal Üniversitesi Sosyal Bilimler Enstitüsü Dergisi, 6 (11) , 1-21.

Güneş, F. (2013). Türkçe öğretimi: yaklaşım ve modeller. Ankara: Pegem Akademi.

Karasar, N. (2013). Bilimsel araştırma yöntemi. Ankara: Nobel yayıncılık.

Korkmaz, T. (2005). Türk eğitim sistemi ve İngiliz eğitim sisteminin karşılaştırılması. (Yüksek lisans tezi). Uludağ Üniversitesi Sosyal Bilimler Enstitüsü, Bursa.

Maarif Vekâleti (1924). Lise birinci devre müfredat programı. İstanbul: Matbaa-i Amire

Maarif Vekâleti (1929). Orta mektep ve liselerin Türkçe müfredat programı, Ankara: Yeni Gün Matbaası.

Maarif Vekâleti (1930). ilk mektep müfredat programı. İstanbul: Devlet Matbaası.

Maarif Vekâleti (1931). Orta mektep müfredat programı, (1931-1932 Ders Senesi Tadilatı). İstanbul: Devlet Matbaası.

Milli Eğitim Bakanlığı (1938). Ortaokul Programı. Ankara: Mili Eğitim Basımevi

Milli Eğitim Bakanlığı (1948). Illkokul programı. İstanbul: Milli Eğitim Basımevi.

Milli Eğitim Bakanlığı (1949). Ortaokul programı. Ankara: Milli Eğitim Basımevi.

Milli Eğitim Bakanlığı (1962). Ortaokul programı. Ankara: Milli Eğitim Basımevi.

Milli Eğitim Bakanlığı (1968). Illkokul programı. İstanbul: Millî Eğitim Basımevi.

Milli Eğitim Bakanlığı (1981). Temel eğitim okulları Türkçe eğitim programı. Tebliğler Dergisi.

Milli Eğitim Bakanlığı (2005). Illköğretim Türkçe Dersi Öğretim Programı ve Kılavuzu, Ankara: Devlet Kitapları Müdürlüğü Basımevi.

Milli Eğitim Bakanlığı (2006). Ilköğretim Türkçe dersi öğretim programı ve kılavuzu (6,7, 8.Sınıflar), Ankara: Devlet Kitapları Müdürlüğü Basım Evi.

Milli Eğitim Bakanlığı (2015). Türkçe Dersi (1-8. Sınıflar)Öğretim Programı, Ankara.

Milli Eğitim Bakanlığı (2017). Türkçe Dersi (1-8. Sınıflar)Öğretim Programı, Ankara.

Milli Eğitim Bakanlığı (2018). Türkçe Dersi (1-8. Sınıflar)Öğretim Programı, Ankara.

Melanlığlu, D. (2012). Dinleme becerisine yönelik ölçme değerlendirme çalışmalarında üst biliş stratejilerinin kullanımı. Turkish Studies,7(1), 1583-1595.

Sönmez, V. ve Alacapınar, F. G. (2016). Örneklendirilmiş bilimsel araştırma yöntemleri (Genişletilmiş 4.bs.). Ankara: Anı Yayıncılık.

Temel Eğinli, A. (2011). Kültürlerarası yeterliliğin kazanılmasında kültürel farklılık eğitimlerinin önemi. ÖNERi Dergisi, 9(35), 215-227

Temizkan, M. ve Atasoy, A. (2014). Cumhuriyet dönemi Türkçe eğitimi ve öğretimi programlarında yazma becerisi. Ana Dili Eğitimi Dergisi, 2(2), 42-71. 